\title{
RESEARCH AND DEVELOPMENT IN THE SERVICE SECTOR - VAGUE DEFINITION AND PROBLEMATIC APPLICATION
}

\author{
Ewa W. MARUSZEWSKA, Marzena STROJEK-FILUS \\ University of Economics in Katowice
}

\begin{abstract}
:
It is a well-known fact that research and development (R\&D) activities are an important factor in maintaining a business on the market. Nowadays, not only is conducting R\&D crucial for entities from new technology sector, but also for companies from each sector, including service entities. The aim of the study was to investigate R\&D activities among the biggest publicly traded entities in Poland and to examine the way economists and engineers understand the notion of R\&D. We hypothesize and find that R\&D expenditure is underestimated or unrecognized in financial reports disclosed by service sector enterprises. Further, we surveyed professional economists and engineers to investigate their knowledge about R\&D notion and ability to distinguish operational (day-to-day) actions from R\&D activities. The study results indicated difference between the opinions expressed by economists and engineers. Our findings are important for regulators and practitioners as they pinpoint that a substantial change in the definition of R\&D is required in order to facilitate a wider adoption of R\&D by companies rendering services.
\end{abstract}

Key words: research and development, financial reporting, definition

\section{INTRODUCTION}

Research and development (R\&D) is in the scope of interdisciplinary interests. A growing number of publications are devoted to current processes of internationalization, multinationalization, and globalization of R\&D activities.

Table 1

The types of $R \& D$ cooperation

\begin{tabular}{|c|c|}
\hline Term & Explanation \\
\hline $\begin{array}{l}\text { Internationali- } \\
\text { zation } \\
\text { of R\&D }\end{array}$ & $\begin{array}{l}\text { Occurs when two or more industrial firms, } \\
\text { research bodies or universities from differ- } \\
\text { ent countries carry out joint R\&D programs } \\
\text { and activities. }\end{array}$ \\
\hline $\begin{array}{l}\text { Multinationali- } \\
\text { zation } \\
\text { of R\&D }\end{array}$ & $\begin{array}{l}\text { Occurs when an industrial firm has estab- } \\
\text { lished one or more R\&D activities in one or } \\
\text { more countries other than the country of } \\
\text { origin of the parent company. }\end{array}$ \\
\hline $\begin{array}{l}\text { Globalization } \\
\text { of R\&D }\end{array}$ & $\begin{array}{l}\text { Occurs when an industrial firm has devel- } \\
\text { oped a global strategy and vision of its R\&D } \\
\text { activities at both the internal level (in- } \\
\text { house R\&D thought, for instance, interna- } \\
\text { tionalization and multinationalization) and } \\
\text { the external level (R\&D alliances with other } \\
\text { firms, mergers and acquisitions, agree- } \\
\text { ments with universities, national research } \\
\text { bodies or governments from other coun- } \\
\text { tries, participation in worldwide scientific } \\
\text { and technical cooperative programs). }\end{array}$ \\
\hline
\end{tabular}

Source: [23].
Table 1 indicates that R\&D has been characterized by strong divergence and incorporates not only industrial firms, but also governmental agencies, universities, and national research bodies. On the other hand, the literature documents that continuous geographical concentration of R\&D activities in the USA, Japan and Western Europe rather limits the "global" nature of R\&D [18] and introduces triadization of R\&D.

Concentration of R\&D activities can also be observed in Poland, where the differences between Mazovia, Lesser Poland, Upper Silesia, Lower Silesia, Greater Poland and other Polish regions have increased [7]. Poland's case also confirms that small and medium enterprises demonstrate limited competence in the field of R\&D [24]. The Polish $R \& D$ expenditure level is low, but most $R \& D$ activities take place among large enterprises, which is also the case in other countries around the world, including the European Union [26]. Moreover, it was documented that neighboring regions are characterized by similarity in regional specialization, which favors establishing business relations [20]. Firms located in the region are actively engaged in the implementation of R\&D expenditure, especially when strong academic and research centers serve as a source of human capital. The above confirms the need to consider the issue from a viewpoint of international regulations and globalization processes.

Based on the documented fact that large international enterprises are major players in global R\&D expenditure [19], our study concentrates on the understanding of R\&D 
by practitioners with technological and economic background. We explore the definition of $R \& D$ expenditure used for financial reporting as the publicly available data are very often the basis for statistical analysis referring to factors affecting R\&D intensity. Our study is also in line with the existing literature indicating that nowadays in order to maintain strong and stable market position, enterprises must not only conduct R\&D activities but also constantly improve them $[5,13]$. As both service companies and manufacturers need new knowledge in the areas of technology and organization of business operations, one can expect that both groups of enterprises will disclose information proving high R\&D intensity.

In our research, we document the low R\&D intensity among firms in the service industry and we study how the $R \& D$ notion is understood by present and future practitioners, and how they classify certain innovations among research activities or development projects. Our findings add to the existing body of literature by stressing that $R \& D$ intensity in the service industry can be underestimated as some/majority of activities that meet the criteria of R\&D are classified as ongoing business operations. We present some paths for future research as well as propose some regulatory changes in the R\&D definition.

\section{PAST LITERATURE}

Taking into account that globalization of R\&D goes together with globalization of technology, publications about $R \& D$ are not only available in technology, policy journals but also economic ones. The literature review presented below focuses on the determinants of R\&D expenditure, as the amount of money spent on R\&D and disclosed in publicly available financial reports.

Prior research on variables explaining R\&D expenditure has not been conclusive which technology, economic and organizational variables explain consistently the trends and behavior of R\&D. The investigated factors included, e.g., capital intensity, debt to capital ratio, eligibility for the R\&D credit or donations, tax credit, and social responsibility $[3,10,11]$.

The publications dealing with tax issues mainly concentrated on the influence of different tax credits on R\&D intensity. Billings and Fried (1999) found that R\&D tax incentives influence the location of R\&D facilities, and hence the creation of high-technology jobs. Furthermore, their findings showed that the proportion of debt in the firm's capital structure has a negative effect on R\&D activity. Therefore, they argument that equity capital is more suitable for financing R\&D due to uncertain payoff which was also confirmed in a different study held in Poland [1]. On the other hand, Billings and Fried find no evidence that management stockholding or diversification strategy meaningfully influenced R\&D activity.

Another comparative study was conducted among Polish and UK companies by Kargol-Wasiluk and Wyszkowski [14]. Their study also confirmed the importance of tax incentives for R\&D activities; furthermore, it indicated the complexity of Polish tax system and the need for its change. The authors made some suggestions for Polish regulators pointing out the limitations of income tax expenditure in support of R\&D activities and the low level of benefiting from available tax incentives.

Different contribution to the literature was made by Klassen, Pittman, and Reed [15]. Their comparison of US and Canada R\&D expenditure in the scope of tax credit mechanisms and financial reporting principles showed that enterprises (matched on size and industry) differ in their responsiveness to tax incentives depending on whether their financial constrains are binding. In addition, they suggested that operating cash flows, the ability to capitalize development costs, and unusually high earnings affect $R \& D$ investments. Although most of the R\&D research was conducted in the USA, there is one more study directed at Canada which documents that $R \& D$ expenditure originates from economic growth and it suggested that the government can stimulate innovation activities as the economy grows [8].

In the study conducted by $\mathrm{Wu}$ [25] the presence of R\&D tax credit is viewed as positive for private R\&D investments, while federal R\&D funds to the private sector do not play a significant role in affecting private incentive to invest in R\&D. Moreover, higher education is important for R\&D companies as they document that, on average, 10 dollars more of state money on higher education results in about 7 dollars' increase in industrial R\&D spending. Positive and significant impact of tax incentives for R\&D was also confirmed in the study conducted among OECD countries [9, 21]. The author indicated that public sector $R \& D$ (made of universities) and private sector $R \& D$ are complements as expenditure on R\&D performed by universities is significantly positively related to business sector expenditure on R\&D. Moreover, he suggested that countries characterized by strong patent rights appear to have higher R\&D intensities.

Hence there is a vast literature stating that small and young firms are crucial to introduce innovations to the market, one can also find papers referring to small and medium enterprises and their innovation potential. Unfortunately, empirical evidence shows that a larger percentage of young small firms remain with a low percentage of R\&D expenditure [2]. The study was held in Spain and it empirically documented that sectoral characteristics are important variables for R\&D expenditure.

Another line of research studied the influence of R\&D expenditure on different characteristics of the firm. The most often investigated attributes were market value of enterprises and organizational performance. Chojnacki and Kijek [6] showed positive relation between the amount of $R \& B$ expenditure and market value of biotechnology firms. Medcof and Lee [17] found that the effect of $R \& D$ expenditure on firm performance is contingent on the degree to which technology is the critical contingency in an industry and depends on the power of the firm's Chief Technology Officer derived from technical expertise. In addition, there exists R\&D research that deals with earnings manipulation. For example, Osma [22] analyzed the role of board of directors in constraining R\&D spending manipulation and indicated that more independent di- 
rectors have sufficient technical knowledge to identify opportunistic reductions in R\&D motivated by short-term earnings pressure. The issue refers to the confounding effect of the decision to capitalize vs. to expense R\&D outlays. R\&D manipulation is possible as a result of ambiguity of definition of R\&D activities disclosed in financial reports [16]. That is why an independent board is seen as an expert that has firm- and industry- specific knowledge to detect and prevent opportunistic behavior.

\section{HYPOTHESIS DEVELOPMENT}

For the initial verification of the problem with R\&D identification and disclosure, empirical data contained in the consolidated financial reports of companies from the WIG 30 index listed on the Warsaw Stock Exchange have been compiled. The selection of the research sample results from the fact that they are the largest entities listed in public trading in Poland. Data from 2016-2017 were analyzed and on their basis the following questions were posed:

Question 1-Has R\&D been recognized in the financial report as the IA?

Question 2-In case of recognizing R\&D as the IA, what is the percentage of this item in total assets?

Question 3-In case of recognizing R\&D as the IA, what is the percentage of this item in total IA?

Table 2 shows that half of the manufacturing companies report $R \& D$ expenditure. Of the financial sector, trade and other services entities (17), only 4 reported such outlays. Moreover, noteworthy is the significant number of companies that reported the group "Other intangible assets" without specifying what items were included in this group and their share. There is therefore no information as to whether R\&D expenditure has been incurred. It is also worth noting that this item is at a very low level in the structure of assets in most entities that have recognized it.

The above presented investigation indicates the disparity between R\&D identification and disclosure among service and other entities publicly traded on Polish stock market. Based on the above finding, in the next step we investigated the definition of R\&D in the regulation, which - in our opinion - contributes to the difficulty in reporting this component in the financial reports in some sectors of business activity, particularly services.

From the point of financial reporting, the solutions adopted in the International Accounting Standards are particularly important. $R \& D$ is recognized as intangible assets (IA) described in IAS 38 Intangible Assets. IA generated by the entity on its own may be disclosed as assets under certain conditions, in particular: identification, control over assets and probability of future economic benefits. In the case of R\&D, the difficulties stem from distinguishing between research activities and development activities, especially since both are usually carried out under one project. Research activities are recognized as current operating costs and affect the financial result of the period in which they were incurred.
Table 2

Comparison of information on $R \& D$ in financial reports

\begin{tabular}{|c|c|c|c|c|c|c|c|}
\hline \multirow{3}{*}{ Entity } & \multirow{3}{*}{ Sector } & \multirow{2}{*}{\multicolumn{2}{|c|}{$\begin{array}{c}\text { Question } 1 \\
\text { [Yes/No] }\end{array}$}} & \multirow{2}{*}{\multicolumn{2}{|c|}{$\begin{array}{c}\text { Question } 2 \\
\text { [\%] }\end{array}$}} & \multirow{2}{*}{\multicolumn{2}{|c|}{$\begin{array}{c}\text { Question } 3 \\
\text { [\%] }\end{array}$}} \\
\hline & & & & & & & \\
\hline & & 2016 & 2017 & 2016 & 2017 & 2016 & 2017 \\
\hline Lotos & Fuel & Y & $Y$ & 0.09 & 0.05 & 10.0 & 6.1 \\
\hline PGNiG & Fuel & $\mathrm{N}$ & $\mathrm{N}$ & 0 & 0 & 0 & 0 \\
\hline $\mathrm{CCC}$ & Retail & $\mathrm{N}$ & $\mathrm{N}$ & 0 & 0 & 0 & 0 \\
\hline CyfrPolsat & Media & $\mathrm{Y}$ & $\mathrm{Y}$ & 0.63 & 0.93 & 3.1 & 4.3 \\
\hline CDProjekt & Software & Y & $Y$ & 7.09 & 14.5 & 18.6 & 34.2 \\
\hline DINOPL & Retail & $\mathrm{N}$ & $\mathrm{N}$ & 0 & 0 & 0 & 0 \\
\hline ENEA & Energy & Y & $Y$ & 0.02 & 0.02 & 1.02 & 1.2 \\
\hline ENERGA & Energy & $\mathrm{NI}$ & $\mathrm{NI}$ & - & - & - & - \\
\hline AZOTY & Chemical & Y & $Y$ & 0.09 & 0.04 & 2.02 & 1.2 \\
\hline Eurocasch & Retail & $\mathrm{NI}$ & $\mathrm{NI}$ & - & - & - & - \\
\hline JSW & Raw materials & $\mathrm{N}$ & $\mathrm{N}$ & 0 & 0 & 0 & 0 \\
\hline KGHM & Raw materials & $\mathrm{NI}$ & $\mathrm{NI}$ & - & - & - & - \\
\hline KRUK & Financial & $\mathrm{NI}$ & $\mathrm{NI}$ & - & - & - & - \\
\hline LPP & Retail & $\mathrm{Y}$ & $\mathrm{Y}$ & 0.14 & 0.07 & 11.8 & 4.6 \\
\hline ORANGE & Telecom. & $\mathrm{NI}$ & $\mathrm{NI}$ & - & - & - & - \\
\hline KERNEL & Food & $\mathrm{NI}$ & $\mathrm{NI}$ & - & - & - & - \\
\hline PGE & Energy & Y & $Y$ & 0.02 & 0.02 & 2.4 & 1.33 \\
\hline PKNORL & Fuel & $\mathrm{NI}$ & $\mathrm{NI}$ & - & - & - & - \\
\hline PKPCargo & Transpo & $\mathrm{NI}$ & $\mathrm{NI}$ & - & - & - & - \\
\hline PLAY & Telecom. & $\mathrm{NI}$ & $\mathrm{NI}$ & - & - & - & - \\
\hline TAURON & Energy & $Y$ & $Y$ & $\sim 0$ & $\sim 0$ & 0.03 & 0.09 \\
\hline SANPL & Financial & Y & $Y$ & 0.05 & 0.03 & 53.1 & 27.3 \\
\hline Alior & Financial & $Y^{*}$ & $\mathrm{Y}^{*}$ & 0.42 & 0.49 & 50.29 & 62.18 \\
\hline MBank & Financial & $\mathrm{NI}$ & $\mathrm{NI}$ & - & - & - & - \\
\hline Millennium & Financial & $\mathrm{N}$ & $Y$ & $\sim 0$ & $\sim 0$ & $\sim 0.0$ & 0.04 \\
\hline IngBSK & Financial & $\mathrm{Y}$ & $\mathrm{Y}$ & 0.02 & 0.02 & 6.3 & 6.5 \\
\hline PEKAO & Financial & Y & $Y$ & $\sim 0$ & $\sim 0$ & 0.56 & 0.14 \\
\hline PKO BP & Financial & $\mathrm{NI}$ & $\mathrm{NI}$ & - & - & - & - \\
\hline PZU & Insurance & $Y$ & $Y$ & 0.14 & 0.08 & 12.1 & 7.3 \\
\hline GTC & Real property & $\mathrm{N}$ & $\mathrm{N}$ & 0 & 0 & 0 & 0 \\
\hline
\end{tabular}

Source: own study based on the financial reports' analysis

Key: $\mathrm{Y}-\mathrm{Yes}, \mathrm{N}-\mathrm{No}$, NI-No information

* $R+D$ costs related to software and licenses without separate recognition

Research has been defined as an innovative and planned search for solutions undertaken with the intention of acquiring and assimilating new scientific and technical knowledge. This group of expenses also includes:

- the search for, evaluation and final selection of, the applications of research findings or other knowledge,

- the search for alternatives for materials, devices, products, processes, systems or services,

- the formulation, design, evaluation and final selection of possible alternatives for new or improved materials, devices, products, processes, systems or services.

On the other hand, the costs of development activities can be, after meeting the following (additional) conditions, disclosed in the report as IA. The main feature of development activities is the practical application of research results or other knowledge in planning or designing new or significantly improved materials, devices, products, technological processes, systems or services. It is important that these activities take place before mass production starts or technology is implemented. Examples of such activities mainly relate to manufacturing: 
- the design, production and testing of pre-production and pre-use models, tools, instruments, for machining, molds and dies involving new technology as well as a pilot plant,

- the design, production and testing of a chosen alternative for new or improved materials, devices, products, processes, systems and services.

While the provisions on production activities are clear, the reference to service activities is only summed up under the headings, in a very general manner, without any explanation or example. Development costs can be recognized as assets only if the entity is able to prove [IAS $38, \S$ 57]:

- the technical feasibility of completing the IA so that it will be available for use or sale,

- its intention to complete the IA and use or sell it,

- its ability to use or sell the IA,

- how the IA will generate probable future economic benefits,

- availability of adequate technical, financial and other resources to complete the development and use or sell the IA,

- its ability to measure reliably the expenditure attributable to the IA incurred during its development.

The definition of R\&D is also stipulated in the guidelines provided by the Organization for Economic Co-operation and Development (OECD) ${ }^{1}$ [21]. The manual emphasizes that $R \& D$ should be distinguished from science and technology, education and training as well as science and technology services. According to OECD regulations, the concept of R\&D includes three types of activity: basic research, applied research and experimental development. Basic research is defined as experimental or theoretical activity undertaken to gain new knowledge of the underlying foundations of phenomena and observable facts, without any particular application or use in view. In turn, applied research is original investigation undertaken to acquire new knowledge directed toward a specific, practical goal. Experimental development has been defined as systematic work, drawing on existing knowledge obtained as a result of research activities and/or practical experience, which is directed to producing new materials, products or devices, or to initiating new or significantly improving existing processes, systems or services. The manual contains numerous examples at the boundaries between $R \& D$ and other production activities with an explanation of what should be recognized as R\&D. In the case of the service sector, the boundaries between R\&D activities and other innovative activities are much more difficult to define.

Based on the definitional condition of R\&D, the following hypothesis was advanced:

$H$ : R\&D for the services sector requires a more precise definition to facilitate its recognition and proper disclosure in the financial reports.

\section{METHODOLOGY AND RESULTS}

The survey questionnaire was conducted among parttime students of two public universities in Poland. The University of Economics and the Technology University, both from Katowice, were chosen in order to compare the knowledge and opinions of economists and engineers. In the first part of the survey, the respondents were asked to decide whether the scenarios present research, development or day-to-day activities. All the scenarios dealt with development activities that comply with the definitions presented above, but three described the changes in organization of work (ergonomics and technology), while the last one presented the development of a new product offered by service companies. The first part of the questionnaire ended with two questions verifying the knowledge of subjects related to the difference between research and development activities. The second part of the questionnaire was aimed at investigating subjects' opinions about the importance of selected factors on the decision about the initiation of R\&D project and about the influence of R\&D on entity's situation. The responders were asked to rank the items presented in the questionnaire in this part of the study.

The study consisted of 142 subjects who have an undergraduate degree in economics ( $n=72 ; 50.7 \%$ ) and technology $(n=70 ; 49.3 \%)$ and have already gained admission to a part-time master's degree course. Mining, environmental, and production engineering education prevailed among the engineers. The subjects were between 22 to 70 years old, many of them were women ( $n=92 ; 64.8 \%$ ). Only 2 subjects had no professional experience, while most of respondents $(65 ; 45.7 \%)$ declared professional experience up to 5 years. Among economists many worked in financial sector (mainly accounting service enterprises or banks; $n=27$ ), electromechanical or hard coal industries $(n=10)$, sales sector $(n=4)$ or new technology entities $(n=3)$. The engineers worked mainly in logistics entities ( $n=17$ ), electromechanical or hard coal sector $(n=11)$, automobile industry $(n=9)$, sales enterprises ( $n$ $=9)$, and new technology entities $(n=4)$. The majority of them were middle-level employees working in private entities with Polish capital ( $n=65 ; 45.7 \%$ ) or employed in foreign capital entities ( $n=55 ; 38.7 \%$ ). It is interesting that a large number of them works in large entities (employing more than 250 employees; $n=68 ; 47.8 \%$ ), while the next group of subjects is employed in micro- and small entities ( $n=53 ; 37.3 \%)$.

Our results showed that respondents are competent and have appropriate knowledge to differentiate between research and development activities (Table 3).

Table 3

Knowledge about the notion of research and development the frequency of correct answers.

\begin{tabular}{lcc}
\hline $\begin{array}{c}\text { Knowledge test } \\
\text { - definitions }\end{array}$ & Economists & Engineers \\
\hline Research activities & $\mathrm{n}=45(63 \%)$ & $\mathrm{n}=32(46 \%)$ \\
Development activities & $\mathrm{n}=54(75 \%)$ & $\mathrm{n}=38(54 \%)$ \\
\hline
\end{tabular}

${ }^{1}$ The Proposed Standard Practice for Surveys of Research and Experimental Development, are known as OECD's Frascati Manual, www.oecd.org 
No statistical differences were found between answers given by economists and engineers in the above-presented knowledge test. Research activities were most often confused with basic research ( $n=20$ among economists and $n=29$ among engineers), while development activities with research ( $\mathrm{n}=17$ among economists and $\mathrm{n}=30$ among engineers).

The part of the survey containing 4 separate scenarios presented detailed descriptions of different business situations that may occur in service rendering companies. The first scenario presented a case with a development related to changes in ergonomics of employees' work in an automobile company rendering assembly services. The second scenario presented an entity which decided to change the amount of gas used in a technological process. The third scenario was about an authorized service center which prepared a manual for service employees aimed at decreasing repair costs, while the last scenario presented a post office which successfully developed a new product offered to the customer. All the scenarios were built in the same way. The introductory part described the situation of the entity defining the problem. Then the solution developed in the entity was presented with a clear indication that the development was successfully completed, and future economic benefits are expected.

It can be observed (Table 4) that the number of correct answers was higher among economists than among engineers. However, based on the $U$ Mann-Whitney test $(U=$ 1829; $p=.002$ ), the difference between economists and engineers was found only in the first scenario. The development activities described in the scenarios were most often confused with operational activities. It can also be observed that the scenario with the development of a new product (No. 1 - service rendered to customers) was the easiest case for respondents to identify the correct answer. In this situation, the percentage of wrong answers was the smallest among all four cases, both for economists and engineers. The results show (Table 5) that the scores for scenarios No. 1, No. 2, and No. 3 were significantly lower than for scenario No. 4. This indicates that the subjects more often chose the wrong answers (operational or research activities) than the right one (development activity). It suggests that it is easier to link an invention of a new product with a development activity than an improvement of existing processes.

Table 5

Wilcoxon test results

Scenario No 1 Scenario No 2 Scenario No 3 and and and

Scenario No 4 Scenario No 4 Scenario No 4

\begin{tabular}{lccc} 
Test statistic & $Z=-3.143$ & $Z=-2.655$ & $Z=-2.862$ \\
Asymptotic & $p<.002$ & $p<.008$ & $p<.004$ \\
Sig. & & & \\
\hline
\end{tabular}

The third part of the questionnaire provided insights into the importance of several factors that may decide whether the entity starts development activities. Using a 5-point Likert scale, the respondents indicated the importance of each factor. " 6 " stood for the most important factor, while " 1 " for the least important one. Figure 1 shows the mean results for factors influencing the decision about starting R\&D activity.

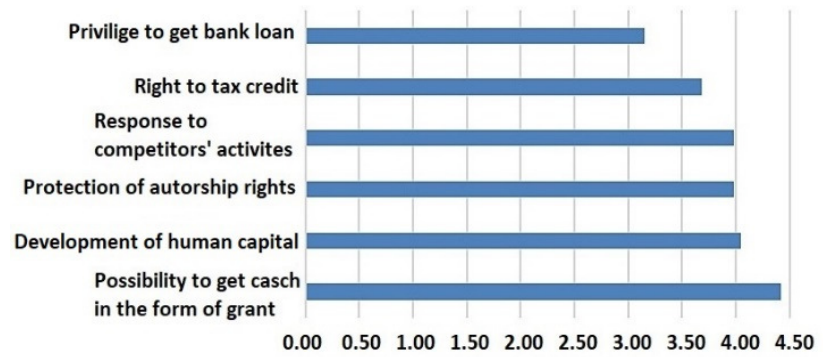

Fig. 1 Mean of answers relating to factors influencing the decision about $R \& D$ activities

Identification of development activities - the percentage of wrong classification

\begin{tabular}{|c|c|c|c|}
\hline Scenario & Classification of activity & Economists & Engineers \\
\hline \multirow{4}{*}{$\begin{array}{l}\text { No 1: } \\
\text { work ergonomics } \\
\text { in assembly automobile company }\end{array}$} & Development activity = correct answer & $n=25(35 \%)$ & $\mathrm{n}=9(13 \%)$ \\
\hline & Operational activity & $\mathrm{n}=28(39 \%)$ & $n=43(61 \%)$ \\
\hline & Wrong identification & $n=18(25 \%)$ & $\mathrm{n}=17(24 \%)$ \\
\hline & Other & $\mathrm{n}=1(1 \%)$ & $\mathrm{n}=1(1 \%)$ \\
\hline \multicolumn{2}{|c|}{ Wrong identification in total } & $n=47(65 \%)$ & $n=61(87 \%)$ \\
\hline \multirow{4}{*}{ No 2: changes in technology } & Development activity = correct answer & $n=21(29 \%)$ & $\mathrm{n}=11(16 \%)$ \\
\hline & Operational activity & $n=28(39 \%)$ & $\mathrm{n}=34(49 \%)$ \\
\hline & Wrong identification & $\mathrm{n}=22(31 \%)$ & $n=23(33 \%)$ \\
\hline & Other & $n=1(1 \%)$ & $n=2(3 \%)$ \\
\hline \multicolumn{2}{|c|}{ Wrong identification in total } & $n=51(71 \%)$ & $n=59(84 \%)$ \\
\hline \multirow{4}{*}{$\begin{array}{l}\text { No 3: } \\
\text { manual for authorized service } \\
\text { center }\end{array}$} & Development activity $=$ correct answer & $\mathrm{n}=26(36 \%)$ & $\mathrm{n}=17(24 \%)$ \\
\hline & Operational activity & $n=31(43 \%)$ & $\mathrm{n}=41(59 \%)$ \\
\hline & Wrong identification & $n=14(19 \%)$ & $\mathrm{n}=11(16 \%)$ \\
\hline & Other & $\mathrm{n}=1(1 \%)$ & $\mathrm{n}=1(1 \%)$ \\
\hline \multicolumn{2}{|c|}{ Wrong identification in total } & $n=46(64 \%)$ & $n=53(76 \%)$ \\
\hline \multirow{5}{*}{$\begin{array}{l}\text { No 4: } \\
\text { a new product of post office } \\
\text { company }\end{array}$} & Development activity = correct answer & $n=33(46 \%)$ & $\mathrm{n}=30(43 \%)$ \\
\hline & Operational activity & $n=31(43 \%)$ & $\mathrm{n}=14(20 \%)$ \\
\hline & Wrong identification & $\mathrm{n}=8(11 \%)$ & $\mathrm{n}=24(34 \%)$ \\
\hline & Other & $\mathrm{n}=0(0 \%)$ & $n=2(3 \%)$ \\
\hline & g identification in total & $\mathrm{n}=39(54 \%)$ & $n=40(57 \%)$ \\
\hline
\end{tabular}


Our findings show that the most important factor to decide about R\&D activation in business entities is the possibility to raise cash in the form of donation, e.g., from the European Union funds. The difference between the mean of the most important factor and the next three factors is considerable suggesting that the lack of appropriate grants may be a crucial obstacle for Polish entities to decide about launching R\&D works. The least importance was assigned to the privilege of obtaining a bank loan at a below-market interest rate.

When the decision is already made and entity carries R\&D works, maintaining the leader position on the market is the most important result indicated by respondents (Figure 2).

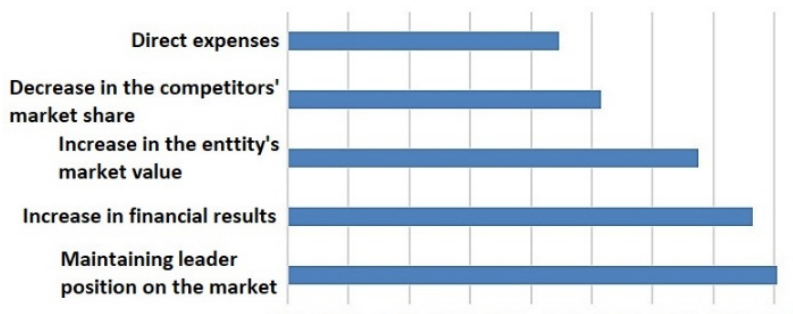

$\begin{array}{llllllllll}0.00 & 0.50 & 1.00 & 1.50 & 2.00 & 2.50 & 3.00 & 3.50 & 4.00 & 4.50\end{array}$

Fig. 2 Mean of answers relating to areas of business activity items affected by $R \& D$

The possibility to expense R\&D directly to income statement is the least important result of R\&D activities. Combining this indication with the previous findings of the study (i.e., with the first part of the questionnaire, when the subjects often classified R\&D activities as operational activities causing increase in expenses), one may conclude that classification of R\&D as operational activity is not influenced by the willingness to increase expenses and thus decrease financial results.

\section{DISCUSSION}

Our study indicated a divergence in the identification and disclosure of R\&D among the biggest Polish entities listed in public trading. Further, we surveyed professionals with economic and technical background and found that although they have the knowledge about the notion of R\&D and they were aware of the difference between research activities and development works, it was hard for them to correctly distinguish between operational (day-to-day) activities and R\&D works. This confirmed our hypothesis that the definition included in the present law does not pinpoint the most important attributes of R\&D, and therefore our results indicate problems with the application of theoretical knowledge in business practice. General nature of legal regulations does not facilitate the application of rules, especially when it comes to service rendering entities. We found that the most difficult are development activities not connected with the invention of new product (service) but arising from the improvement of existing products (services) or from the advancement of technology in use. When changing Polish regulations or/and developing an R\&D manual of good practices, it may be useful to highlight examples indicated in Frascati Manual. It describes the following criteria that should help define R\&D activities:

- connected with public research laboratories,
- engagement of employees with a doctoral degree or doctoral candidates,

- publication of research results in scientific journals, organization of scientific conferences.

Further, attention is drawn to situations in which the results of R\&D (conducted as part of the service activity) are then embedded in computer software, which from a technical point may not have the value of innovation; however from the point of its functions it can fulfill this condition.

As Frascati Manual indicates that additional difficulty in classifying R\&D may also be the lack of formal organization of this activity (e.g., through a separate, special R\&D department), in our study we clearly described that a project team was formulated. Although we eliminated this difficulty, the results still show hardship in classification, both in the group of economists and engineers. As our survey was based on cases imbedded in service rendering entities, we conclude that the concept of R\&D is still too vague, and $R \& D$ may often remain unrecognized in service-rendering enterprises. The criteria for R\&D identification and examples of such activities for the service sector require further development and investigation.

\section{CONCLUSIONS}

$R \& D$ costs are increasingly important for the development, competitiveness and market position of entities. The need to invest more in R\&D is related to the regulations of the accounting law regarding the principles and conditions for recognizing these outlays as assets in financial and other business reporting. Our research focused on the understanding of R\&D by practitioners with technological and economic background. The results of the conducted research have shown that in the case of service sector entities, definitions and R\&D criteria are ambiguous and difficult to apply, which may be a significant obstacle to their proper recognition in the financial reports. Difficulties in classifying R\&D can lead to recognition of all costs as operating costs, which, if significant, may violate faithfulness of reporting and provide distorted managerial information to different inner decision makers. In the paper we also investigated R\&D activities among the biggest publicly traded entities in Poland. Our study indicates the disparity between R\&D identification and disclosure among service and other entities. This part of the research corresponds with the results of the survey study. We call for further research examining crucial characteristics of R\&D that may help economists and engineers apply theory into practice. We also suggest that additional regulatory explanation is needed, for example in the form of manual adopted to both groups of professionals involved in R\&D: economists and engineers.

\section{REFERENCES}

[1] A. Adamczyk. „Poziom wewnętrznych źródeł finansowania jako determinanta inwestycji w działalność B+R przedsiębiorstw." Prace Naukowe Uniwersytetu Ekonomicznego we Wrocławiu, 323, 13-22, 2013.

[2] D.B. Audretsch., A. Segarra, M. Teruel. "Why don't all young firms invest in R\&D?" Small Business Economy, 43, 751-766, 2014. 
[3] W. Biały, J. Žarnovský. „Acquiring EU funds for the development of research potential of enterprises as a method for developing smart specialisations". Acta Technologica Agriculturae, 20(2), 46-51, 2017. https://doi.org/10.1515/ata-2017-0009

[4] B.A. Billings, Y. Fried. "The effects of taxes and organizational variables on research and development intensity". R\&D Management, 29(3), 289-301, 1999.

[5] K. Brożek, J. Kogut. „Ekonometryczna analiza zarządzania działalnością B+R w polskich przedsiębiorstwach". Edukacja Ekonomistów i Menadżerów. Problemy, Innowacje, Projekty, 2(44), 145-160, 2017.

[6] P. Chojnacki, T. Kijek. „Wydatki na prace badawczo-rozwojowe a wartość rynkowa firm biotechnologicznych". Prace Naukowe Uniwersytetu Ekonomicznego we Wrocławiu, 439, 59-67, 2016.

[7] D. Chybowska, L. Chybowski. "R\&D in Poland: is the country close to a knowledge economy?" Management Systems in Production Engineering, 26(2), 99-105, 2018.

[8] V. Doyar. "R\&D expenditures by field of science and GDP: which causes which in Canada?" Economics and Business Letters, 8(1), 31-40, 2019.

[9] M. Falk. "What drives business research and development (R\&D) intensity across Organisation for Economic Co-operation and Development (OECD) countries?" Applied Economics, 38, 533-547, 2006. https://doi.org/10.1080/00036840500391187

[10] R.K. Goel. "The substitutability of capital, labor and R\&D investment in US manufacturing". Bulletin of Economic Research, 42(3), 211-223, 1990.

[11] P. Hąbek. "Implementacja społecznej odpowiedzialności jako innowacji - wybrane przykłady". Prace Naukowe Uniwersytetu Ekonomicznego we Wrocławiu, 100, 146-161, 2010.

[12] International Accounting Standards Board, "International Accounting Standard No 38 Intangible Assets", 2004.

[13] P. Kaczmarczyk. „Ekonometryczna analiza rozwoju działalności badawczo-rozwojowej polskiego sektora ICT w latach 2007-2014". Zeszyty Naukowe Państwowej Wyższej Szkoły Zawodowej w Płocku, XXIII, 55-70, 2016.

[14] A. Kargol-Wasiluk, A. Wyszkowski. „Preferencje podatkowe wspierające działalność $B+R$ w ramach podatków dochodowych w Polsce i w Wielskiej Brytanii". Prace Naukowe Uniwersytetu Ekonomicznego we Wrocławiu, 451, 145-161, 2016.

\section{Ewa Wanda Maruszewska}

ODCID ID: 0000-0003-0461-4133

University of Economics in Katowice

College of Finance

Department of Business Informatics

and International Accounting

ul. 1 Maja 50, 40-287 Katowice, Poland

e-mail: ewa.maruszewska@ue.katowice.pl

\section{Marzena Strojek-Filus}

ORCID ID: 0000-0001-7073-9191

University of Economics in Katowice

College of Finance

Department of Accounting

ul. 1 Maja 50, 40-287 Katowice, Poland

e-mail: marzena.strojek@ue.katowice.pl
[15] K.J. Klassen, J.A. Pittman, M.P. Reed. "A cross-national comparison of R\&D expenditure decisions: tax incentives and financial constraints". Contemporary Accounting Research, 21(3), 639-680, 2004.

[16] D. Mangala, M. Dhanda. "Earnings management: conceptual framework and research developments". The IUP Journal of $\backslash$ Accounting Research \& Audit Practices, XVII(4), 7-20, 2018.

[17] J.W. Medcof, T. Lee. "The effects of the chief technology officer and firm and industry R\&D intensity on organizational performance". R\&D Management, 47(5), 767-781, 2017. http://dx.doi.org/10.1111/radm.12275

[18] A. Odrobina. „Kierunki i tendencje procesu koncentracji działalności badawczo-rozwojowej korporacji transnarodowych". International Business and Global Economy, 35(2), 379-391, 2016.

[19] A. Odrobina. „Korporacje transnarodowe a globalna dziatalność badawczo-rozwojowa”. Prace Naukowe Uniwersytetu Ekonomicznego we Wrocławiu, 267, 144-154, 2012.

[20] A. Odrobina, P. Folfas. „Intensywność nakładów na badania i rozwój w regionach Unii Europejskiej w ujęciu przestrzennym". International Business and Global Economy, 37, 142-156, 2018.

[21] OECD's Frascati Manual. https://www.oecd.org, 2015. [September 01, 2019]

[22] B.G. Osma. "Board independence and real earnings management: the case of R\&D expenditure". Corporate Governance, 16(2), 116-131, 2008.

[23] R. Petrella. "Internationalization, multinationalization and globalization of R\&D: toward new division of labor in science and technology?" Knowledge and Policy: The International Journal of Knowledge Transfer and Utilization, 5(3), 3-25, 1992.

[24] M. Piekut, J. Pacian. „Przestrzenne zróżnicowanie nakładów na działalność badawczo-rozwojową na przełomie wieków". Economics and Management, 4, 205-224, 2013.

[25] Y. Wu. "The effect of state R\&D tax credits in stimulating private R\&D expenditure: a cross-state empirical analysis". Journal of Policy Analysis and Management, 24(4), 785802, 2005.

[26] A. Zygmunt. „Poziom nakładów na B+R w Polsce na tle pozostałych państw Unii Europejskiej”. Prace Naukowe Uniwersytetu Ekonomicznego we Wrocławiu, 393, 163-171, 2015. 